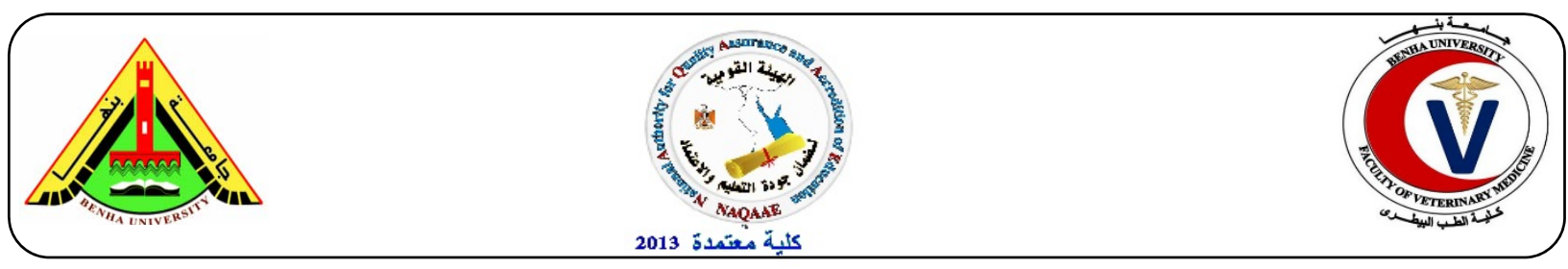

\title{
Effect of housing system and sex ratio of quails on egg production, fertility and hatchability.
}

Karousa, M.M., Souad A. Ahmed, Elaithy, S.M. and Eman A. Elgazar.

Department of Animal Hygiene, Behavior and Management, Faculty of Veterinary Medicine, Benha University, Egypt.

\begin{abstract}
A B S T R A C T
The objective of this work was to evaluate the effect of housing system and sex ratio of quails on egg production, fertility and hatchability. A total number of 305 quails of five weeks old were divided into two groups, The first group (96 birds) was housed on battery cages and divided according to sex ratio into 2 equal subgroups of ratio (1:2) male to females and 1:3, the second one (209 birds) was housed on floor pens and divided according to sex ratio into 2 equal subgroups of ratio (1:2) male to females and 1:3. Eggs were collected daily for one month to estimate egg production percentage of each group. 200 eggs from each group were artificially incubated for detection the effect of housing on fertility, hatchability and embryonic mortality. The obtained results showed that the total egg production percentage was significantly higher $(P<0.001)$ in case of battery cages $(63.54 \pm 1.68 \%)$ than those in floor system $(46.67 \pm 1.68 \%)$, it was higher but not significant at sex ratio $1: 3(57.01 \pm 1.68 \%)$ than those at $1: 2$ $(53.21 \pm 1.68 \%)$. The fertility percentage was significantly higher $(P<0.001)$ in case of floor pens $(80.67 \pm 0.75 \%)$ than those in battery cages $(73.67 \pm 0.75 \%)$ and significantly higher $(P<0.01)$ at sex ratio $1: 2(79.17 \pm 0.75 \%)$ than those at $1: 3(75.17 \pm 0.75 \%)$. The hatchability percentage of total eggs set was higher but not significant in floor pens $(52.00 \pm 1.89 \%)$ than those in battery cages $(49.50 \pm 1.89 \%)$, it was higher but not significant at sex ratio $1: 3(52.00 \pm 1.89 \%)$ than those at $1: 2(49.50 \pm 1.89 \%)$. The hatchability percentage of fertile eggs set was significantly higher $(P<0.001)$ in battery cages $(70.40 \pm 0.90 \%)$ than those in floor pens $(64.45 \pm 0.90 \%)$ and significantly higher $(P<0.001)$ at sex ratio $1: 3(70.12 \pm 0.90 \%)$ than those at $1: 2(64.75 \pm 0.90 \%)$.
\end{abstract}

Key words: Japanese quails, Housing, Egg production, Fertility, Hatchability.

(http://www.bvmj.bu.edu.eg) conference issue

(BVMJ-28(2): 241-247, 2015)

\section{1- INTRODUCTION}

Q uails have been farmed since ancient times. The earliest known representation of the quail can be found in the Egyptian hieroglyphics (2000 B.C), where the quail represents the letter "W" in the alphabet (Shanaway, 1994). Quails are reared in multi-tiers cages both during growing and laying periods. However, quails are also being reared on floor equally well and system of housing did not affect the quail's egg production (Padmakumar et al., 2000). Housing system is the most important factor affecting poultry performance (Roshdy et al., 2010). Cage reared quail had higher egg production than that reared on littered floor (Alam et al., 2008). System of rearing of Japanese quail did not influence the fertility level significantly (Arumugam et al., 2014). Fertility was higher in Japanese quail reared on floor and lowers in cages (Farooq et al., 2001). The highest percentage of fertility was found in $1: 1 \quad(92.21 \%)$ and $1: 2$ $(91.18 \%)$ male: females mating ratio as compared to 1:4 and 1:5 mating groups of Japanese quail (Dogan et al., 2013). Production system had significant effect on hatchability of total eggs of Japanese quail set but did not significantly affect hatchability of fertile eggs, Hatchability of 
eggs from caged birds was $62.34 \%$ as compared to $37.35 \%$ from deep litter reared birds and hatchability of fertile eggs was 69.63 and $67.96 \%$ respectively (Raji et al. 2014). There was significant effect of mating ratio on hatchability of Japanese quail eggs. They obtained hatchability values of $84.6 \%$ and $85.2 \%$ at mating ratios of $1: 2$ and 1:3, respectively. The effect of male: female ratios on the hatchability of fertile eggs were found non-significant, whereas the effect of this ratio on the hatchability of total eggs was significant (Ipek et al., 2004).

\section{2- MATERIALS AND METHODS}

\subsection{The birds}

A total number of 305 quails of five weeks old and of an average weight 140-150gm were sexed by using external appearance and the colour of breast feather, the breast of male is dull of dark yellowish orange colour, while female quails are usually larger and have a lighter shade of color on the breast which is sprinkled with small black spots. Birds were divided into 2 groups according to housing system, the first group has 96 birds transferred to breeding batteries and divided into 8 equal subgroups (12 birds each), 4 subgroups (48 birds) has 4 males to 8 females with mating ratio 1male: 2 females, while other 4 subgroups (48 birds) has 3 males to 9 females with mating ratio 1 male to 3 females. Each subgroup was housed in a separate cage $(60 \mathrm{~cm}$ length $\times 50 \mathrm{~cm}$ width $\times 25 \mathrm{~cm}$ height at front and $20 \mathrm{~cm}$ height at rear of cage). The second group has 209 birds transferred to floor pen $(200 \mathrm{~cm}$ length x $150 \mathrm{~cm}$ width $\times 300 \mathrm{~cm}$ height) and divided to 2 subgroups. The first subgroup has 35 males to 70 females with mating ratio 1male: 2 females, while the second subgroup has 26 males to 78 females with mating ratio 1male: 3 females.

\section{2-2-Housing system}

As a routine work the house was thoroughly cleaned and disinfected before arrival of quails by fumigation with formaldehyde gas according to the recommendation of (Sainsbury and Sainsbury 1982).

\section{2-2-1- The battery system}

battery of 5 tires vertically arranged, each tire containing two laying cages measured $60 \mathrm{~cm}$ length $\times 50 \mathrm{~cm}$ width $\times 25$ $\mathrm{cm}$ height at front and $20 \mathrm{~cm}$ height at rear of cage, floor of cage is made from welded wire mesh $(2 \times 1 \mathrm{~cm})$ through which dropping fall down into underneath tray. Ration was provided through long narrow feeders located in front of the cages, while water was provided through water troughs at the back of cages, eggs rolled on the sloping cage floor and collected in front of laying cages. The feeder and waterer spaces were $5 \mathrm{~cm}$ per bird. Moreover, cages provide $250 \mathrm{~cm} 2 /$ bird space allowance for each.

\section{2-2-2-Deep litter system (floor pens)}

In this system, the floor was covered with a clean dry soft wood shaving 10-12 $\mathrm{cm}$ depth after sprinkling slaked lime over the floor. Throughout the experiment any wet or caked spots around feeders and drinkers were removed and replaced with clean and dry litter material, litter for all groups were periodically replaced. Feed was supplied in feeding trough while water was supplied in plastic drinkers. The feeder and waterer spaces were $5 \mathrm{~cm}$ per bird.

Floor pens were $(200 \mathrm{~cm}$ length $\mathrm{x} 150 \mathrm{~cm}$ width $x 300 \mathrm{~cm}$ height). Floor pens provide $250 \mathrm{~cm} 2 /$ bird space allowance for each.

\section{2-3-Feeding}

Birds were fed ration according to (Nutrients requirements of poultry, 1994) for one week on ration contains $23 \%$ protein, (El wadi company). When the birds began laying, they were fed on a ration contains $18 \%$ protein, (El wadi company).

\section{2-4- Measurments}

2-4-1- Egg production 
Eggs used in the study were collected 2 weeks after the quails begin laying eggs. Eggs were collected 3 times daily at 10:00 am, 5:00pm and 10:00pm. The eggs produced by each experimental group were daily collected, recorded and individually weighted by using digital balance
(Sartorius) ${ }^{\circledR}$ then placed in crates with broad end up. For measuring egg production: Eggs number was counted daily for 1 month to know which mating ratio from each housing systems give more eggs production than other.

number of eggs laid per day
Daily egg production $(\%)=$

Egg selection for incubation: Number of collected eggs for incubation: A total number of 400 eggs were collected over 4 to 5 Consecutive days (200 eggs from each housing system, 100 eggs for each mating ratio). The selected eggs for incubation were sound, clean, and normal in shape with good shell quality and with normal size (10$15 \mathrm{gm})$. All eggs which were too small size less than $10 \mathrm{gm}$, too large size, soft shell, cracked, broken, dirty, miss shape and with pores shell were discarded. Each egg was marked with a permanent mark to indicate (housing system and sex ratio).

Storage and preparing eggs for incubation: Eggs were stored for 5 days at $14^{\circ} \mathrm{C}$, at $\mathrm{RH}$ $75 \%$ and turned twice a day period of 5 days according to (Roshdy et al., 2010).

Eggs were sprayed with (virkon ${ }^{\circledR}$ ) disinfectant (15gm powder / liter water) after collection.
Egg incubation: Eggs were set at automatic incubator on trays with large end up at temperature $37.5^{\circ} \mathrm{C}$ and at $\mathrm{RH} 65 \%$, with manually turning according to (Dauda et al., 2014) every 6 hours for 15 days and then for last two days of incubation eggs were set on boxes with wood shaving in the floor of incubator for hatching at temperature of $36.5{ }^{\circ} \mathrm{C}$ and at R.H $75 \%$. After the end of incubation period (17 days), hatched eggs were detected from number of hatched chicks, the non-hatched eggs were collected and counted, then opened and the contents were macroscopically examined to determine fertile, non-fertile eggs and embryonic death. Infertile eggs had no blood islet while fertile ones had blood islet or dead embryo according to (Raji et al., 2014).

\section{2-4-2- Fertility}

Fertility was calculated as:

$$
\text { Fertility }(\%)=\frac{\text { No. of hatched eggs }+ \text { No. of eggs containing embryo }}{\text { Total No. of incubated eggs }} \times 100
$$

\section{2-4-3- Hatchability}

Hatchability was calculated as:

$$
\begin{aligned}
& \text { Hatchability of total eggs }(\%)=\frac{\text { No. of hatched chicks }}{\text { No. of incubated eggs }} \times 100 \\
& \text { Hatchability of fertile egg }(\%)=\frac{\text { No. of hatched chicks }}{\text { No. of fertile eggs }} \times 100
\end{aligned}
$$

These parameters were measured according to (Ozcelik et al., 2006). 
by the General Linear Model (GLM) procedure of the SAS statistical analysis system package (SAS, 2002). Least Squares Means (LSM) \pm standard errors were calculated and tested for significance using "T" test.

\section{3- RESULTS:}

3.1. Effect of housing system and sex ratio on the egg production percentage of Japanese quail.

Quails reared on battery cages characterized by significantly higher egg production than quails reared on floor pens. While quails housed with mating ratio 1male: 3 females produced more eggs than quails housed with mating ratiolmale: 2 females but this difference was non-significant (Table1).

\subsection{Effect of housing system and sex ratio on the fertility, hatchability of Japanese quail.}

The fertility rate showed the best results in quails of floor pens system than battery cages while housing system not affect the hatchability of total eggs set; on the other hand, the hatchability of fertile eggs set was higher in cage system than floor pens system. While fertility was higher in sex ratio 1 male : 2 females than in 1male:3females while hatchability of fertile eggs higher in sex ratio 1male:3females than 1male:2females and hatchability of total eggs set not affected by sex ratio (Table 2).

Table (1): Least square means and standard errors ( $\bar{X} \pm$ S.E) for the effect of housing system and sex ratio on the total egg production $(\%)$ of Japanese quail.

\begin{tabular}{lc}
\hline \multicolumn{1}{c}{ Items } & $\begin{array}{c}\text { Total egg production } \\
(\%)\end{array}$ \\
\hline $\begin{array}{l}\text { Housing system } \\
\text { Battery cages }\end{array}$ & $63.54 \pm 1.68^{\mathrm{a}}$ \\
Floor pens & $46.67 \pm 1.68^{\mathrm{b}}$ \\
& \\
Sex ratio & \\
(male-female) & \\
$1: 2$ & $53.21 \pm 1.68^{\mathrm{a}}$ \\
$1: 3$ & $57.01 \pm 1.68^{\mathrm{a}}$ \\
\hline
\end{tabular}

Means with the same letter at the same column are not significantly different.

Table (2): Least square means and standard errors ( $\bar{X}_{ \pm}$S.E) for the effect of housing system and sex ratio on the fertility and hatchability (\%) of Japanese quail eggs.

\begin{tabular}{lccc}
\hline \multicolumn{1}{c}{ Items } & $\begin{array}{c}\text { fertility } \\
(\%)\end{array}$ & $\begin{array}{c}\text { Hatchability of total eggs set } \\
(\%)\end{array}$ & $\begin{array}{c}\text { Hatchability of fertile eggs set } \\
(\%)\end{array}$ \\
\hline $\begin{array}{l}\text { Housing system } \\
\text { Battery cages }\end{array}$ & $\begin{array}{c}73.67 \pm 0.75^{\mathrm{b}} \\
\text { Floor pens }\end{array}$ & $49.50 \pm 1.89^{\mathrm{a}}$ & $70.40 \pm 0.90^{\mathrm{a}}$ \\
Sex ratio & & $52.00 \pm 1.89^{\mathrm{a}}$ & $64.45 \pm 0.90^{\mathrm{b}}$ \\
(Male-female) & & & \\
$1: 2$ & $79.17 \pm 0.75^{\mathrm{a}}$ & $49.00 \pm 1.89^{\mathrm{a}}$ & $64.75 \pm 0.90^{\mathrm{b}}$ \\
$1: 3$ & $75.17 \pm 0.75^{\mathrm{b}}$ & $52.50 \pm 1.89^{\mathrm{a}}$ & $70.12 \pm 0.90^{\mathrm{a}}$ \\
\hline
\end{tabular}

Means with the same letter at the same column are not significantly different.

\section{4- DISCUSSION}

Data presented in Table (1) showed the effect of housing system and sex ratio on the total egg production (\%) of Japanese quail. The total egg production percent was $63.54 \pm 1.68$ and $46.67 \pm 1.6 \%$ for the quails reared on the battery cages and floor pens, respectively. From the obtained results, it is clear that there were highly significant differences $(P<0.001)$ in the total egg production due to the housing system. The highest egg production in cage housed-birds may be attributed to the lowest egg loss in battery system than floor pens. The obtained results in the present study were in agreement with Arumugam et al., (2014) and Gandhimathi et al., (2014) who found 
that egg production of Japanese quail is about $80 \%$ in cage system and $70 \%$ in deep litter system. On the other hand, the obtained results disagreed with Roshdy et al., (2010) who recorded that quails kept on floor pens had significantly higher values in egg number than those kept in battery cages. Regarding the effect of sex ratio, the total egg production percent was $53.21 \pm 1.68$ and $57.01 \pm 1.68 \%$ for sex ratio $1: 2$ and $1: 3$ (male: female), respectively. The obtained results revealed that there were non significant differences $(P \geq 0.05)$ in the total egg production due to sex ratio. These results agreed with Al-Rawi (1980) who found that presence of male had no significant effect on egg production. Data presented in Table (2) showed the effect of housing system and sex ratio on the fertility (\%) of Japanese quail eggs. The fertility percentage was $73.67 \pm 0.75$ and $80.67 \pm 0.75 \%$ for the quails reared on the battery cages and floor pens, respectively. From the obtained results, it was observed that the fertility percentage was higher in floor pens than battery system, there were highly significant differences $(P<0.001)$ in the fertility percentage due to the housing system. The highest fertility percentage in floor housed-birds may be attributed to the absence of leg and peak abnormalities which are essential for successful mating behavior and also due to the more freedom of males to mate with females on floor pens and the lowest aggressive pecking percentage, while the lowest fertility in cage-housed birds may be attributed to presence of high incidence of legs and beak abnormalities and the highest aggression and fighting between males which interfere with mating behavior. Similar result was obtained by (Farooq et al., 2001) and Meizar et al., (2008) who reported that the fertility percentage was higher in deep-litter system than battery system. On the contrary, those results disagreed with Roshdy et al., (2010); Arumugam et al., (2014) who found that system of rearing of Japanese quail did not influence the fertility level significantly. Also, Raji et al., (2014) recorded that fertility percent of eggs from caged birds was 89.54as compared to 54.93from deep litter reared birds. Regarding the effect of sex ratio, the fertility percentage was $(79.17 \pm 0.75 \%)$ and $(75.17 \pm 0.75 \%)$ for sex ratio $1: 2$ and $1: 3$ (male: females), respectively. From the obtained data, it was observed that the fertility percentage was higher in sex ratio1:2 than 1:3, there was high significant difference $(P<0.001)$ in fertility due to sex ratio. The higher average of fertility percentage in sex ratio 1:2 may be attributed to the female received more mounting than those in case of $1: 3$. The obtained results in the present study are in agreement with Dogan et al., (2013) who concluded that fertility percentage of sex ratio 1:2 $(91.18 \%)$ was higher than sex ratiol:3 (86.41\%). Also, Ali et al., (2013) found that fertility percentage of sex ratio $1: 2(74 \%)$ was higher than sex ratiol:3 (70\%). On the other hand, the obtained results disagreed with Ipek et al., (2004) who found that there were non significant differences in fertility percentage between sex ratio 1:2 (94.44\%) and 1:3(94.77\%). Results in Tables (2) showed the effect of housing system and sex ratio on the hatchability percent of Japanese quail eggs. The hatchability percentage of total eggs set was $49.50 \pm 1.89$ and $52.00 \pm 1.89 \%$ for the quails reared on the battery cages and floor pens, respectively. From the obtained results, it is clear that the hatchability percentage of total eggs set was lower in cage reared birds than floor pens reared birds but there were non significant differences $(P \geq 0.05)$ in the hatchability percentage of total eggs set due to the housing system. These results were similar to those reported by Meizar et al., (2008); Roshdy et al., (2010) who showed non significant difference between two housing systems in hatchability. Our results are disagreed the findings of Arumugam et al., (2014) who found that there was significant difference in hatchability of total eggs set of Japanese quails between deep litter and cage systems of rearing. Also, Raji et al., (2014) recorded that hatchability of eggs 
from caged birds was $62.34 \%$ as compared to $37.35 \%$ from deep litter reared birds. Regarding the effect of sex ratio, the hatchability percentage of total eggs set was $49.00 \pm 1.89$ and $52.50 \pm 1.89 \%$ for sex ratio 1: 2 and 1: 3 (male: females), respectively. From the obtained data, it is clear that hatchability percentage of total eggs set was higher in sex ratio 1:3 than 1:2, but there was non significant difference $(P \geq 0.05)$ in the hatchability of total eggs set due to sex ratio. These results agreed with those reported by Ipek et al., (2004); Raji et al., (2014) who found that hatchability of total eggs higher in mating ratio (male:female) 1:3 (65.87\%) than $1: 2(20.83 \%)$. On the other hand, the obtained results are disagreed with Seker et al., (2005) who found statistically higher effect of mating ratio in hatchability of quail's egg. Table (2) also revealed that the average of hatchability percentage of fertile eggs set was $70.40 \pm 0.90$ and $64.45 \pm 0.90 \%$ for the quails reared on the battery cages and floor pens, respectively. From the obtained results, it is clear that the hatchability percentage of fertile eggs set was higher in cage reared birds than floor pens reared birds; there were highly significant differences $(P>0.001)$ in the hatchability percentage of fertile eggs set due to the housing system. These results were similar to those reported by Chidananda et al., (1986); Meizar et al., (2008) who found that hatchability of fertile eggs was higher in quails reared in cages than quails reared in deep litter. Our results are contrary to the findings of Arumugam et al., (2014) who found that deep litter rearing resulted in significantly higher hatchability on fertile eggs. Also, Raji et al. (2014) found that production system did not significantly affect hatchability of fertile eggs. Regarding the effect of sex ratio, the average of hatchability percentage of fertile eggs set was $64.75 \pm 0.90$ and $70.12 \pm 0.90 \%$ of sex ratio 1: 2 and 1: 3 (male: females), respectively. From the obtained data, it was observed that the average of hatchability percentage of fertile eggs set was higher in sex ratio1:2 than 1:3, there was higher significant difference $(P<0.01)$ in hatchability of fertile eggs sets due to sex ratio. These results agreed with those reported by Baser et al., (2002) who concluded that the best mating ratio of male and females was 1:3 for optimum hatchability of fertile eggs of Japanese quail. Also, Raji et al. (2014) found that hatchability of fertile eggs higher in mating ratio (male : female) 1:3 (71.48\%) than $1: 2$ $(26.32 \%)$. On the other hand, the obtained results are disagreed with Ipek et al., (2004); Ali et al., (2013) who found non-significant differences in hatchability of fertile eggs of quail between mating ratio $1: 2(68.50 \%)$ and $1: 3(66.63 \%)$.

\section{5- CONCLUSION}

From the obtained results it could be concluded that housing quails in battery cages with mating ratio 1 male :3females leads to increase of total egg production and improve hatchability of fertile eggs set. Maximum fertility rate occurred when quails, reared on deep litter system.

\section{6- REFERENCES}

Alam, M.S.M., Howlider, A.R., Mondal, A., Hossain, K., Rubayet Bostami, A.B.M. 2008. pattern of egg production in Japanese quail reared on littered floor and in cage, Bangladesh Research Publications Journal, 1(3):239-249.

Ali, U., Sarzamin Khan, Rafiullah, Naila Chand, Zahid Ali Shah, Amanullah Akhtar, Abdul Jabbar Tanweer. 2013. Effect of male to female ratio and vitamin-E Selenium on fertility, hatchability and hatched chick weight of quail breeders. Sarhad J. Agric. 29: (3).

Al-rawi, B.A. 1980. Sex Ratio Effects on Egg Production. Poultry Science 59:1546-1547.

Arumugam, R., Prabakaran, R., Sivakumar, T. 2014. Hatching performance of pure Japanese quail breeders under 
cage and deep litter systems of rearing. Journal of Global Biosciences, 3(7):1105-1110.

Baser, E., Erensayin, C., Orhan, H. 2002. The effect of mating interval and different sex ratio on reproductive performance and some yielding traits of Japanese quail. J. Cen. Ani. Res. Inst. 12:216-220.

Chidananda, B.L., Prathapkumar, K.S., Sreenivasaiah, P.V., Ramappa, B.S., Lokanath, G.R. 1986. Comparative performance of japanese quail on cage and deep litter (2) egg production and reproductive traits. Indian J. Poult. Sci., 21(2):91-96.

Dauda, G., Momoh, O.M., Dim, N.I., Ogah D.M. 2014. Growth, production and reproductive performance of japanese quails (coturnix coturnix japonica) in humid environment. Egypt. Poult. Sci. 34(II):381-395.

Dogan Narinc, Ali Aygun, Tolga Sari. 2013. Effects of cage type and mating ratio on fertility in Japanese quails (Coturnix Coturnix Japonica) eggs. Agriculture Science Developments, 2(1): 4-7.

Farooq, M., Aneela, K., Durrani, F. R., Muqarrab, A. K., Chand, N., Khurshid, A. 2001. Egg and shell weight, hatching and production performance of Japanese broiler quails. Sarhad J. Agri. 17: 289-293.

Gandhimathi, A., Babu, M., Asha rajini, R., Sujatha, S., Lurthu Reetha, T. 2014. Effect of nest box on the reproductive performance of Japanese quail.J ournal Of International Academic Research for Multydisciplinary, 2: (5).

Ipek, A., Sahan, U., Yilmaz, B. 2004. The effect of live weight, male to female ratio and breeder age on reproduction performance in Japanese quails (Coturnix coturnix japonica), South African Journal of Animal Science, 34 (2):130-134.

Meizar, E.M., Karousa, M.M., Elgendi, G.M., Ahmed, S.A., Mahmoud, E.A.
2008. Study on effect of some managerial factors on behavior and performance of quail. Master. Department of Animal Hygiene, Behavior and Management, Faculty of Veterinary Medicine, Benha University, Egypt.

Nutrients requirements of poultry, 1994. 9th revised Ed. National Academy Press. Washington, D.C., USA.

Ozcelik, M., Cerit, H., Ekmen, F., Dogan, I. 2006. Effect of the hatching month as an environmental factor on the hatching features of Bronze Turkey. Turk. J. Vet. Anim. Sci., 30:243-249.

Padmakumar, B., G., Reghunathan Nair, A., Ratnakrishnan, A.K.K., Unni, N., Ravindr ana than. 2000. Effect of floor space on egg weight and egg quality trait of Japanese quails reared in cages and deep litter. Journal of Veterinary and Animal Sciences, 31: 34-36.

Raji, A., S., Mbap , G., Mohammed , I., Kwari. 2014. Fertility and hatchability of Japanese quail eggs under semi arid conditions in Nigeria. Agricultural Science and Technology, 6(4): $455-459$.

Roshdy, M., Khalil, H.A., Hanafy, A.M., Mady, M.E. 2010. Productive and Reproductive Traits of Japanese Quails as affected by Two Housing System.Egypt. Poult. Sci. J. 30(1):5567

Sainbury and Sainbury, 1982. Poultry Health and Management. Fourth edition. p:166-171.

SAS (2002): SAS/STAT users guide. SAS Institute INC, Cary, NC 27513, USA.

Seker, I., Kul, s., Bayraktar, M. 2005. Effects of storage period and egg weight of Japanese quail eggs on hatching results. Arch. Tierz. Dummerstorf. 48(5): 518-526.

Shanaway, M.M.1994. Quail production systems. A review. Animal production and health division, FAO Rome, Italy. 